\title{
The Gastroscopic Findings of the Pediatric Patients With Hematemesis
}

\section{Çocuk Acil Polikliniğine Hematemesis Şikayetiyle Başvuran Hastaların Gastroskopik Bulguları}

\author{
(D) Sinem Oral Cebeci ${ }^{1}$, (D) Hasret Ayyıldız Civan² \\ ${ }^{1}$ Istanbul University-Cerrahpaşa Faculty of Medicine Department of Pediatric Emergency, Istanbul, Turkey \\ 2University of Health Sciences Turkey, İstanbul Dr. Sadi Konuk Training and Research Hospital, Clinic of Pediatric Gastroenterology, İstanbul, \\ Turkey
}

\begin{abstract}
Objective: Hematemesis is a common symptom of upper gastrointestinal bleeding, bleeding from the mouth that appears fresh red or looks like "coffee grounds." It is a rare, life-threatening emergency condition and potentially requires emergency intervention in children. Our study aims to evaluate the gastroscopy findings of pediatric patients who presented with vomiting of blood.

Methods: Seventy children and adolescents (35 females, 35 males) presented with hematemesis were evaluated retrospectively. Patients' demographic characteristics, gastroscopic findings, pre- and post-operative laboratory results were compared and evaluated.

Results: Male patients $(6.91 \pm 5.21)$ were significantly younger than female patients $(10.51 \pm 4.79)$ at the time of diagnosis $(p=0.005)$. Of these, $92.9 \%$ had no symptoms. According to the gastroscopy findings performed at the time of diagnosis, the underlying pathology was detected in $65.7 \%$ of cases. Esophagitis was the most common pathology with a rate of $52.2 \%$ and followed by pangastritis (30.4\%). As a result of posttreatment gastroscopy, $21.7 \%(n=15)$ of cases had pathological findings. Moreover, the mean hemoglobin value measured during diagnosis was significantly lower in cases with underlying pathology according to post-treatment gastroscopy results $(p=0.025)$.

Conclusion: Hematemesis was observed at an early age in male children with a higher rate of underlying pathology after treatment. In addition, the significantly low hemoglobin levels reported in the cases with positive gastroscopy have reaffirmed the diagnostic and therapeutic importance of gastroscopy. It has also highlighted the requirement for immediately monitoring vital symptoms following the patient's admission.
\end{abstract}

Keywords: Upper gastrointestinal bleeding, hematemesis, gastroscopy, children, adolescents

\section{öz}

Amaç: Hematemez, kanın taze kırmızı veya "kahve telvesi" şeklinde ağızdan geldiği, üst gastrointestinal sistem kanamasının yaygın bir semptomudur. Hayatı tehdit edebilecek acil bir durum olarak tanımlanır ve potansiyel olarak çocuklarda acil müdahale gerektirir. Çalışmamızda kanlı kusma ile başvuran çocuk hastaların gastroskopi bulgularını değerlendirmeyi amaçladık.

Gereç ve Yöntem: Hematemez ile başvuran 70 çocuk ve ergen (35kız, 35 erkek) geriye dönük olarak değerlendirildi. Hastaların demografik özellikleri, gastroskopik bulguları, ameliyat öncesi ve sonrası laboratuvar sonuçları karşılaştırıldı ve değerlendirildi.

Bulgular: Tanı anında erkek hastalar $(6,91 \pm 5,21)$ kadın hastalardan $(10,51 \pm 4,79)$ anlamlı olarak daha gençti $(p=0,005)$. Hastaların \%92.9'unda herhangi bir belirti yoktu. Tanı anında yapılan gastroskopi bulgularına göre; vakaların \%65,7'sinde altta yatan patoloji tespit edildi. Özofajit $\% 52,2$ ile en sık görülen patoloji olup, onu pangastrit $(\% 30,4)$ izledi. Tedavi sonrası gastroskopi sonucunda olguların \%21,7'sinde ( $n=15)$ patolojik bulgular vardı. Ayrıca tanı sırasında ölçülen ortalama hemoglobin değerinin altta yatan patolojisi olan olgularda tedavi sonrası gastroskopi sonuçlarına göre istatistiksel olarak daha düşük olduğu tespit edildi $(p=0,025)$.

Sonuç: Tedavi sonrası altta yatan patoloji oranı daha yüksek olan erkek çocuklarda daha erken yaşta hematemez görüldü. Ek olarak, gastroskopi bulgusu pozitif olan olgularda bildirilen önemli ölçüde düşük hemoglobin seviyeleri, gastroskopinin tanısal ve terapötik önemini yeniden teyit etmiştir. Ayrıca, hastanın yatışını takiben yaşamsal semptomların derhal izlenmesinin gerekliliğini vurgulamıştır.

Anahtar Kelimeler: Üst gastrointestinal kanama, hematemez, gastroskopi, çocuklar, ergenler

Address for Correspondence: Hasret Ayyıldız Civan, University of Health Sciences Turkey, İstanbul Dr. Sadi Konuk Training and Research Hospital, Clinic of Pediatric Gastroenterology, İstanbul, Turkey

Phone: +90 5057479765 E-mail: hasretayyildiz@yahoo.com ORCID ID: orcid.org/0000-0002-5604-9722

Cite as: Ayyıldız Civan H, Oral Cebeci S. The Effect of Nurse Telephone Consultation After Coronary Artery Bypass on The Autonomy Level Of Elderly Patients: Quasi - Experimental Study. Med J Bakırköy 2021;17:149-153

Received: 14.03.2021

Accepted: 16.06.2021 


\section{INTRODUCTION}

In children, upper gastrointestinal bleeding (UGIB) is a rare condition. Its reported an annual incidence is $1-2 / 10,000$ with high mortality risk (1). Hematemesis is a relatively common symptom of a UGIB, and defined as bleeding from the mouth that appears fresh red or looks like "coffee grounds." Although hematemesis most frequently occurs due to benign causes, it carries a serious mortality potential that may require urgent intervention (2).

The etiology of hematemesis is heterogeneous and varies with age, comorbidity, and geographic location in children. In Western countries, Mallory-Weiss tears, gastric and duodenal ulcers, esophagitis, gastritis, and esophagealgastric varices are the most common underlying etiology of UGIB in children $(1,2)$. Hematemesis and/or melena typically accompany UGIB. Hematemesis usually indicates that the lesion causing the bleeding is above the Treitz ligament. Fresh hematemesis is a reliable marker of active bleeding. Laboratory tests seldomly contribute to the diagnosis. However, laboratory tests are necessary for controlling thrombocytopenia and coagulopathy (3). After detailed anamnesis and physical examination, endoscopy is the gold standard diagnostic and therapeutic tool. The bleeding focus can be identified, and re-bleeding can be prevented via endoscopy $(3,4)$.

In the clinical management of the patient, resuscitation should be evaluated primarily by focusing on their hemodynamic stability by monitoring vital symptoms, such as heart rate, blood pressure, and capillary refill time. Then, the patient should be symptomatically treated until the diagnostic processes are completed (5). In our study, we aim to evaluate the gastroscopy findings of pediatric patients who presented with vomiting of blood.

\section{METHODS}

\section{Sample}

This study was performed with the Institutional Review Board protocol approval date July 20, 2020, and number 2020/15 in İstanbul Bakırköy Dr. Sadi Konuk Training and Research Hospital between April 1, 2017, and April 1, 2020. In this study, 70 children and adolescents aged between 0 and 18 years who presented with hematemesis were evaluated retrospectively. Exclusion criteria for the current study were the presence of any known esophageal, gastric, duodenal, and chronic liver diseases.

\section{Measures}

A cell blood count analysis was performed on patients' venous blood samples. Hematological parameters were analyzed using a hematology analyzer (Cell-Dyne 3700, Abbott, Abbott Park, IL, USA). Biochemical analysis performed from serum samples by electro-chemiluminescence immunoassay on Beckman Coulter Unicel DXI 800 analyzer. The blood prothrombin time (PT) and international normalized ratio (INR) were measured by automated coagulation analyzer CS2100i (Sysmex Corporation, Kobe, Japan).

Patients' demographic characteristics, gastroscopic findings, and pre- and post-operative laboratory results were recorded and evaluated.

\section{Statistical Analysis}

All the data were analyzed with Statistical Package for the Social Sciences (SPSS) software for Windows (v21.0; IBM, Armonk, NY, USA). Individual and aggregate data were summarized using descriptive statistics, including means, standard deviations, medians (min-max), frequency distributions, and percentages. The normality of data distribution was verified by the Kolmogorov-Smirnov test. Comparison of the variables with normal distribution was made with Student's t-test. The variables that were not normally distributed were compared using the MannWhitney and Kruskal-Wallis tests. Categorical variables were evaluated by the chi-square test. P-values of $<0.05$ were considered statistically significant.

\section{RESULTS}

This study included 70 hematemesis cases, of which 35 were females (50.0\%), 35 were males (50.0\%), and the mean age was $8.71 \pm 5.29$ (range: $0-18$ ) years. In addition, the mean age of female patients $(10.51 \pm 4.79$ years) was significantly higher than male patients (6.91 \pm 5.21 years) $(p=0.017)$ (Table 1).

While $92.9 \%(n=65)$ of patients had no complaints, two patients presented with abdominal pain and melena, and one patient with pallor. However, a history of drug use was reported by two patients (2.9\%); no oral findings were found in any patient time of diagnosis, the underlying pathology was detected in $65.7 \%(n=46)$ of cases. Esophagitis was the most common pathology with a rate of $52.2 \%(n=24)$ and was followed by pangastritis (30.4\%) $(n=14)$. Of these

Table 1. The mean age and gender analysis of the cases

\begin{tabular}{llll}
\hline & $\mathrm{n}(\%)$ & $\begin{array}{l}\text { Age (month) } \\
(\text { mean } \pm \text { SD) }\end{array}$ & $\mathrm{p}$ \\
\cline { 1 - 3 } Male & $35(50.0 \%)$ & $6.91 \pm 5.21$ & \multirow{2}{*}{$0.005^{\star}$} \\
\cline { 1 - 3 } Female & $35(50.0 \%)$ & $10.51 \pm 4.79$ & \\
\cline { 1 - 3 } Total & $70(100 \%)$ & $8.71 \pm 5.29$ &
\end{tabular}

SD: Standard deviation, ${ }^{*} p<0.05$ statistically significant 
patients, $68.6 \%(n=48)$ received treatment. The proton pump inhibitor (PPI)-sucralfate was the most common treatment protocol, with a rate of $29.2 \%(n=14)$. It was followed by a PPI-sucralfate-domperidone treatment protocol with a rate of $27.1 \%(n=13)$ (Table 2).

As a result of the gastroscopy performed after treatment, the pathological findings were determined in $21.7 \%(n=15)$ of cases, and no pathology was found in 54 cases (78.3\%). According to the evaluation of laboratory findings at the time of diagnosis; the mean values of platelets were $312.2 \pm 133.1 \times 109 / \mathrm{L}$, hemoglobin was $11.29 \pm 2.47 \mathrm{~g} / \mathrm{dL}$, hematocrit was $34.67 \pm 6.97$, INR was $1.12 \pm 0.21$, and PT was $14.02 \pm 2.28$ seconds in our study. No statistically significant differences were found according to the laboratory results and the mean age between the patients with negative and positive gastroscopy findings ( $p>0.05$ ) (Table 3 ). However, the mean hemoglobin value measured during diagnosis was significantly lower in cases with underlying pathology according to the post-treatment gastroscopy results $(p=0.025)$ (Table 4) (Figure1).

Moreover, a significantly higher rate of underlying pathology was detected in patients who received treatment $(29.8 \%$, $\mathrm{n}=14)$ than patients without treatment $(4.5 \%, \mathrm{n}=1)$. In addition, males $(31.4 \%, \mathrm{n}=11)$ had a significantly higher rate of underlying pathology compared with females $(11.8 \%$, $n=4)(p=0.048)$ after treatment. However, the presence of symptoms and the history of drug use during diagnosis were not correlated with post-treatment gastroscopy findings ( $p$-values $=0.204$ and 0.390 , respectively).

\section{DISCUSSION}

Hematemesis in children often requires medical intervention and treatment regardless of underlying etiology, in addition to causing serious anxiety in parents. It has been reported in published data that the risk of UGIB increases with

Table 2. Treatment protocols and frequencies

\begin{tabular}{lll}
\hline Treatment & $\mathbf{n}$ & $\%$ \\
\hline Proton pump inhibitor & 4 & 8.3 \\
\hline Na-aliginate + Na-bicarbonate & 1 & 2.1 \\
\hline PPI - Domperidone & 7 & 14.6 \\
\hline Na-aliginate + Na-bicarbonate - Domperidone & 3 & 6.3 \\
\hline PPI - Sucralfate & 14 & 29.2 \\
\hline PPI - Sucralfate - Domperidone & 13 & 27.1 \\
\hline $\begin{array}{l}\text { PPI - Na-aliginate + Na-bicarbonate - } \\
\text { Domperidone }\end{array}$ & 6 & 12.5 \\
\hline
\end{tabular}

PPI: Proton pump inhibitor

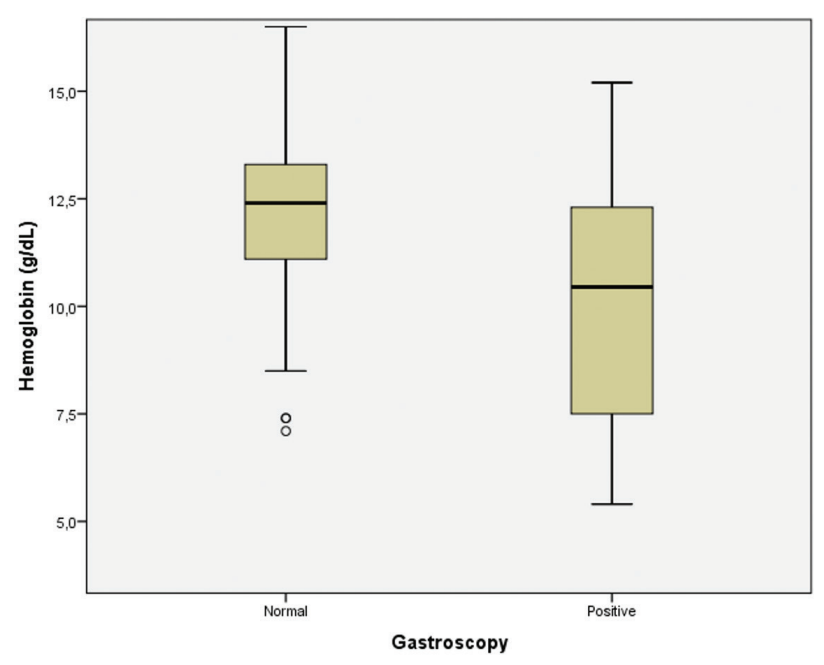

Figure 1. The comparison of mean hemoglobin values according to the post-treatment gastroscopy results

increasing age in children. In a study conducted with 613 patients with hematemesis, Freedman et al. (6) reported that cases with severe hemorrhage had a significantly higher mean age than cases with mild symptoms (mean age 9.7 vs. 2.9 years; $p<0.001$ ). Mihai et al. (7) documented a mean age of 9.7 years in a study consisting of 66 males and 63 females, 95 of whom presented with hematemesis. Similarly, Nasher et al. (8) reported a significantly higher mean age in female patients ( $8.2 \pm 6.0$ years) than male patients ( $5.9 \pm 5.5$ years ) in 32 children ( 17 males, 15 females) who presented with hematemesis (59.3\%) and hematemesis + melena (15.6\%). In accordance with published data, the mean age was $8.71 \pm 5.29$ years in our sample group. In addition, male patients were significantly younger than females. This finding of our study is rather remarkable. To our knowledge, young age and male gender have not been evaluated as risk factors for hematemesis in published data. In this regard, further research should be performed with larger study groups. Results of these studies might enable understanding risk factors in children with hematemesis.

In children, the causes of UGIB usually vary according to geography and age groups. In neonates, coagulation disorders associated with vitamin K deficiency and milk protein intolerance take the first place. In older children, the most common causes of UGIB include swallowing a foreign body in children aged between one month and one year, erosive esophagitis and gastritis in children aged between one and five years, coagulation disorders in children aged between five and 18, and gastritis and erosive esophagitis (9). In a study consisting of 1,218 UGIB patients who presented with hematemesis $(59.3 \%)$, melena (22.6\%), and hematemesis + melena (18.1\%), Yu et al. (10) 
Table 3. The comparison of laboratory findings and gastroscopy results

\begin{tabular}{lllll}
\hline & $\begin{array}{l}\text { Gastroscopy negative } \\
\text { (mean } \pm \text { SD) }\end{array}$ & $\begin{array}{l}\text { Gastroscopy positive } \\
\text { (mean } \pm \text { SD) }\end{array}$ & $\begin{array}{l}\text { Total } \\
\text { (mean } \pm \text { SD) }\end{array}$ & P \\
\hline Age & $7.33 \pm 5.56$ & $9.43 \pm 5.05$ & $14.02 \pm 2.28$ & 0.118 \\
\hline INR & $1.06 \pm 0.28$ & $1.14 \pm 0.17$ & $1.12 \pm 0.21$ & 0.738 \\
\hline PT (sn) & $14.62 \pm 1.72$ & $13.78 \pm 2.46$ & $14.02 \pm 2.28$ & 0.290 \\
\hline Hemoglobin $(\mathbf{g} / \mathbf{d L})$ & $10.85 \pm 2.47$ & $11.46 \pm 2.48$ & $11.29 \pm 2.47$ & 0.570 \\
\hline Hematocrit $(\%)$ & $33.39 \pm 6.74$ & $35.14 \pm 7.09$ & $34.67 \pm 6.97$ & 0.554 \\
\hline Thrombocyte $(\times 10 \% / L)$ & $312.5 \pm 113.5$ & $312.1 \pm 141.3$ & $312.2 \pm 133.1$ & 0.992 \\
\hline INR: International normalized ratio, PT: Prothrombin time, SD: Standard deviation & & & \\
\hline
\end{tabular}

Table 4. The comparison of laboratory findings and post-treatment gastroscopy results

\begin{tabular}{|c|c|c|c|c|}
\hline Laboratory findings & $\begin{array}{l}\text { Gastroscopy negative } \\
\text { (mean } \pm \text { SD) }\end{array}$ & $\begin{array}{l}\text { Gastroscopy positive } \\
\text { (mean } \pm \text { SD) }\end{array}$ & $\begin{array}{l}\text { Total } \\
\text { (mean } \pm \text { SD) }\end{array}$ & $p$ \\
\hline PT (sn) & $14.01 \pm 2.42$ & $14.04 \pm 2.03$ & $14.02 \pm 2.28$ & 0.971 \\
\hline INR & $1.10 \pm 0.23$ & $1.16 \pm 0.14$ & $1.12 \pm 0.21$ & 0.519 \\
\hline Hemoglobin (g/dL) & $11.82 \pm 2.12$ & $9.97 \pm 2.88$ & $11.29 \pm 2.47$ & $0.025^{\star}$ \\
\hline Hematocrit (\%) & $36.16 \pm 5.52$ & $31.02 \pm 8.97$ & $34.67 \pm 6.97$ & 0.075 \\
\hline Thrombocyte $\left(\times 10^{9} / \mathrm{L}\right)$ & $295.0 \pm 124.8$ & $353.7 \pm 151.9$ & $312.2 \pm 133.1$ & 0.174 \\
\hline
\end{tabular}

${ }^{*} \mathrm{p}<0.05$ statistically significant, INR: International normalized ratio, PT: Prothrombin time, SD: Standard deviation

documented erosive gastritis (33.5\%) as the most common endoscopic finding, followed by duodenal ulcer (23.2\%) and gastric ulcer (9.0\%). In another study consisting of 80 pediatric patients with hematemesis, the most commonly reported endoscopic findings were esophageal varices at a rate of $30.0 \%$, followed by gastritis (26.3\%) and duodenitis ulcer (25.0\%) (11). Similarly, Freedman et al. (6) reported the most common endoscopic finding as esophageal/ gastric varies at a rate of $26 \%$ in their study conducted with 613 hematemesis patients. In our study, the underlying pathology was detected in $65.7 \%$ of cases. Esophagitis was the most common pathology with a rate of $52.2 \%$ and was followed by pangastritis (30.4\%).

Although aspirin and other non-steroidal anti-inflammatory drugs have been associated with UGIB in children in some published studies, the etiological value of drugs for UGIB is not entirely understood because the data was obtained from a few studies with small sample group sizes and case reports (12). Mazigh et al. (13) reported that gastro-toxic drug utilization is an independent risk factor [Odds ratio (OR): 1.3; 95\% confidence invertal (Cl): 0.8-2.3] for bleeding by multivariate logistic regression analysis in their study conducted with 489 pediatric patients with hematemesis. Also, Grimaldi-Bensouda et al. (12) associated NSAID utilization, such as ibuprofen and aspirin, with UGIB in a 2-year study consisting of 177 children. In our study, while the history of drug use was found only in $2.9 \%$ of cases, the history of drug use during diagnosis was not significantly associated with post-treatment gastroscopy findings.

In children, a diagnostic approach for hematemesis is usually provided by the data obtained from the studies related to adult diagnoses. Currently, the key point in the diagnostic approach is the evaluation of laboratory and endoscopy findings combined with detailed anamnesis and physical examination. However, a differential diagnosis should be applied for lower gastrointestinal bleeding and non-Gl sources $(4,13)$. There are limited published data comparing laboratory outcomes between positive and negative endoscopy results in children with hematemesis. Cleveland et al. (14) performed endoscopy in 2569 UGIB cases, $73.4 \%$ of whom presented with hematemesis. Researchers reported a bleeding source in $57 \%$ and no underlying pathology in $11.4 \%$ of cases. In addition, $29.7 \%$ of cases were documented as suspicious positive. However, no significant differences were found regarding the mean hemoglobin values between the negative pathology $(12.0 \pm 2.3 \mathrm{~g} /$ $\mathrm{dL})$ and suspicious positive $(11.6 \pm 2.3 \mathrm{~g} / \mathrm{dL})$ groups. Also, researchers reported significantly lower hemoglobin levels in the cases with duodenal erosion/ulceration $(8.3 \pm 2.8 \mathrm{~g} /$ $\mathrm{dL})$ and varices $(7.7 \pm 2.3 \mathrm{~g} / \mathrm{dL})$ (14). Similarly, our study found no significant differences between patients with negative and positive gastroscopy findings at the time of diagnosis 
according to the mean hemoglobin values. However, as a result of the control gastroscopy performed after treatment, the underlying pathology was determined in $21.7 \%$ of cases. According to the post-treatment gastroscopy results, the mean hemoglobin value measured during diagnosis was statistically lower in the cases with underlying pathology.

\section{CONCLUSION}

In conclusion, observing hematemesis at early ages in male children with a higher rate of underlying pathology is remarkable. Whether early age is a risk factor for male children should be re-evaluated by comparing the findings of our study in further research studies with larger sample groups. In addition, the significantly low hemoglobin levels reported in cases with positive gastroscopy have reaffirmed the diagnostic and therapeutic importance of gastroscopy. It has also highlighted the requirement for immediately monitoring vital symptoms following the patient's admission. Therefore, considering the high risk of morbidity in cases with hematemesis, a detailed history, comorbid diseases, drug use, bleeding characteristics, and the physical examination should be evaluated rapidly and carefully using a multidisciplinary approach.

\section{ACKNOWLEDGMENTS}

The authors declare that they have no conflict of interest.

\section{ETHICS}

Ethics Committee Approval: This study was performed with the Institutional Review Board protocol approval date July 20, 2020, and number 2020/15 in İstanbul Bakırköy Dr. Sadi Konuk Training and Research Hospital between April 1, 2017, and April 1, 2020.

Informed Consent: Consent form was filled out by all participants.

\section{Authorship Contributions}

Surgical and Medical Practices: H.A.C., S.O.C., Concept: H.A.C., S.O.C., Design: H.A.C., S.O.C., Data Collection or Processing: H.A.C., S.O.C., Analysis or Interpretation: H.A.C., S.O.C., Literature Search: H.A.C., S.O.C., Writing: H.A.C., S.O.C.

Conflict of Interest: No conflict of interest was declared by the authors.
Financial Disclosure: The authors declared that this study received no financial support.

\section{REFERENCES}

1. Nasher O, Devadason D, Stewart RJ. Upper Gastrointestinal Bleeding in Children: A Tertiary United Kingdom Children's Hospital Experience. Children (Basel) 2017;4:95.

2. Villa X. Approach to upper gastrointestinal bleeding in children. UpToDate [enlínea][consultado el 16/11/2013]. Disponibleen: www. uptod a te. com/contents/approach-to-upper-gastrointestinalbleeding-in-children. 2017.

3. Lirio RA. Management of Upper Gastrointestinal Bleeding in Children: Variceal and Nonvariceal. Gastrointest Endosc Clin N Am 2016;26:63-73.

4. Shahraki T, Shahraki M, Miri-Aliabad G. The importance of endoscopy as a useful method for diagnosis of upper gastrointestinal bleeding in children. J Comp Ped 2018;9:e55022.

5. Mittal SK, Bhattacharya M. Upper gastrointestinal bleeding in children. Indian Journal of practical Pediatrics 2018;20:184-92.

6. Freedman SB, Stewart C, Rumantir M, Thull-Freedman JD. Predictors of clinically significant upper gastrointestinal hemorrhage among children with hematemesis. J Pediatr Gastroenterol Nutr 2012;54:737-43.

7. Mihai L, Balasa A, Mihai CM, Stroia V, Cuzic V, Frecus C, Stoicescu R. 795 Etiology of Upper Gastrointestinal Bleeding in Children. Pediatric Research 2010;68:401.

8. Nasher O, Devadason D, Stewart RJ. Upper Gastrointestinal Bleeding in Children: A Tertiary United Kingdom Children's Hospital Experience. Children (Basel) 2017;4:95.

9. Owensby S, Taylor K, Wilkins T. Diagnosis and management of upper gastrointestinal bleeding in children. J Am Board Fam Med 2015;28:134-45.

10. Yu $Y$, Wang B, Yuan L, Yang $H$, Wang $X$, Xiao $Y$, et al. Upper Gastrointestinal Bleeding in Chinese Children: A Multicenter 10Year Retrospective Study. Clin Pediatr (Phila) 2016;55:838-43.

11. Fatma A, Esraa TA, Faddan MD. Clinical Audit on Management of Hematemesis in Children Admitted to Pediatric Gastroenterology and Hepatology Unit of Assiut University Children Hospital. The Medical Journal of Cairo University 2018;86:4531-6.

12. Grimaldi-Bensouda L, Abenhaim L, Michaud L, Mouterde O, Jonville-Béra AP, Giraudeau B, et al. Clinical features and risk factors for upper gastrointestinal bleeding in children: a casecrossover study. Eur J Clin Pharmacol 2010;66:831-7.

13. Mazigh S, Boukthir S, Hachicha S, Brini I, Sammoud A. Les facteurs cliniques prédictifs de lesions endoscopiques à haut risqué de saignement chez un enfant présentant une hématémèse [Clinical predictors of high risk bleeding endoscopic lesions in children with hematemesis]. Tunis Med 2015;93:454-7.

14. Cleveland K, Ahmad N, Bishop P, Nowicki M. Upper gastrointestinal bleeding in children: an 11-year retrospective endoscopic investigation. World J Pediatr 2012;8:123-8. 